Sifi et al., Afr J Tradit Complement Altern Med. (2015) 12(3):150-155

\title{
ANTIMYCOBACTERIAL, ANTIOXIDANT AND CYTOTOXIC ACTIVITIES OF ESSENTIAL OIL OF GALL OF PISTACIA ATLANTICA DESF. FROM ALGERIA
}

\author{
Sifi ${ }^{a}$ I., Dzoyem ${ }^{b, c}$, J.P., Ouinten ${ }^{a}$, M., Yousfi ${ }^{a}$, M., McGaw ${ }^{b}$ L.J., and Eloff ${ }^{b^{*}}$ J.N. \\ ${ }^{\mathrm{a}}$ Laboratoire des Sciences Fondamentales, Université Amar TÉLIDJI - Laghouat, (03000), Algeria. ${ }^{\mathrm{b}}$ Department of \\ Biochemistry, Faculty of Science, University of Dschang, P.O. Box 67, Dschang, Cameroon. ${ }^{c}$ Phytomedicine \\ Programme, Department of Para clinical Sciences, Faculty of Veterinary Science, University of Pretoria, South Africa. \\ *Corresponding author E-mail: kobus.eloff@up.ac.za, jpzoyem@yahoo.fr
}

\begin{abstract}
Background: The aim of this study was to assess the antimycobacterial, antioxidant and the cytotoxic activities of the essential oil from the gall part of Pistacia atlantica Desf from Algeria.

Materials and Methods: The antimycobacterial activity was evaluated by the broth microdilution method against three species of mycobacteria: Mycobacterium smegmatis, Mycobacterium aurum and Mycobacterium fortuitum. Antioxidant activity was determined using free-radical scavenging assays. The safety of essential oil was assessed by the 3-(4,5-dimethylthiazol-2-yl)-2,5-diphenyltetrazolium bromide (MTT) assay on $\mathrm{C} 3 \mathrm{~A}$ and Vero monkey kidney cells.

Results: The minimal inhibitory concentration (MIC) values ranged from 0.16 to $2.5 \mathrm{mg} / \mathrm{mL}$ with minimal bactericidal concentration (MBC) values ranged from 0.62 to $>2.5 \mathrm{mg} / \mathrm{mL}$. The antioxidant activity showed $\mathrm{IC}_{50}$ values ranged between $417.61->2000 \mu \mathrm{g} / \mathrm{mL}$ and $495.6-$ $>2000 \mu \mathrm{g} / \mathrm{mL}$ for DPPH and ABTS assay respectively. The cytotoxicity assay showed $\mathrm{LC}_{50}$ ranged between 26.47 to $93.64 \mu \mathrm{g} / \mathrm{mL}$ against Vero cells and 74.29 to $225.40 \mu \mathrm{g} / \mathrm{mL}$ against C3A. The results of this study show that the essential oils from the gall of $P$. atlantica have low toxicity and moderate activity against fast growing M. smegmatis and M. aurum.

Conclusion: These results substantiate their potential as used in the treatment of non-tuberculous mycobacterial infections. This finding is predictive of their activity against $M$. tuberculosis, therefore, further study might be considered to investigate the activity against pathogenic Mycobacterium strains.
\end{abstract}

Key words: Pistacia atlantica, Essential oil, Antimycobacterial, Antioxidant, Cytotoxicity.

\section{Introduction}

Pistacia is a genus of Anacardiaceae family. Five species of the genus grow naturally in the Mediterranean basin and Middle East: $P$. lentiscus, P. atlantica, P. palaestina, P. terebinthus and P. khinjuk (Golan-Goldhirsh et al., 2004). P. atlantica Desf. is a source of mastic gum. Exudate is used traditionally against coughs, chills and stomach diseases, to strength gums and as a mouth freshener. The gall of $P$. atlantica known in Arabic as "afse" is edible and used in Algeria as insect repellent (Gourine et al., 2011). Moreover, gall is used in the Sahara as expectorant, against asthma and chest diseases (Ozenda, 2004). According to Martinez (2008), the gall has been shown to protect their occupants from natural enemies, such as predators and parasitoids, by various chemical and mechanical means. Less attention, however, has been given to the possibility of defence against microbial pathogens in the humid and nutrient-rich gall environment. Essential oils have been traditionally used for treatment of infections and diseases all over the world for centuries (Rios \& Recio, 2005). It's gaining remarkable interest for their potential multipurpose use as antioxidant, antibacterial and antiseptic agent (Zanetti et al., 2010).

Several study emphasized the antimycobacterial potential of essential oil (Billo et al., 2005; Raju et al., 2007; Pinto et al., 2009; Zanetti et al., 2010), but their toxicity have rarely been investigated. The antimicrobial and antioxidant activity of essential oil from different part of Pistacia atlantica Desf have been a subject of particular interest to many previous studies (Bachir Raho \& Benali, 2010; Gourine et al., 2011). However, the antioxidant activities of essential oil from gall of this plant species as well as the antimycobacterial activity have not been reported to date. This study describes the antimycobacterial and antioxidant activities, as well as the cytotoxicity of essential oil of gall of Pistacia atlantica Desf from three regions in Algeria.

\section{Materials and Methods \\ Plant samples and essential oil}

The gall of Pistacia atlantica Desf was collected during summer 2011 from three different locations in Algeria: Ä̈n-Oussera, Laghouat and Kheneg; respectively located at 210, 450, 425 kilometres south of Algiers, the capital of Algeria. The identity of the plant material was confirmed by Professor Salima Benhouhou a botanist from The National Institute of Agrononmy in Algeria. The essential oil was obtained by hydro-distillation, using Clevenger type apparatus, during three hours. The obtained essential oil was treated by anhydrous sodium sulphate filtrated and stored at $+4^{\circ} \mathrm{C}$ until analysis.

Antimycobacterial activity assay

Mycobacterial culture

Mycobacterium smegmatis (ATCC 1441), Mycobacterium aurum (NCTC 10437) and Mycobacterium fortuitum (ATCC 6841) were cultured as described by McGaw et al. (2008). They were maintained on Löwenstein-Jensen agar slants, supplemented with glycerol. Inocula suspensions were prepared by mixing a few microbial colonies with sterile distilled water. The suspension was diluted with sterile water to render 


\section{Sifi et al., Afr J Tradit Complement Altern Med. (2015) 12(3):150-155}

a concentration of cells equal to standard $1 \mathrm{McFarland}$ solution (approximately $4 \times 10^{7} \mathrm{cfu} / \mathrm{mL}$ ), and then diluted with freshly prepared Middlebrook $7 \mathrm{H} 9$ broth supplemented with $10 \%$ OADC medium to obtain a final inoculum density of approximately $4 \times 10^{5} \mathrm{cfu} / \mathrm{mL}$.

\section{Determination of minimum inhibitory and bactericidal concentration (MIC and MBC)}

The broth micro-dilution technique using 96-well micro-plates, as described by Eloff (1998) was used to obtain the MIC and MBC values of essential oil samples. A $100 \mu \mathrm{L}$ of each sample of essential oil at an initial concentration of $10 \mathrm{mg} / \mathrm{mL}$ were serially diluted, two-fold in 96-well microtitre plates, with equal volumes of Middlebrook $7 \mathrm{H} 9$ broth. Then, $100 \mu \mathrm{L}$ of inocula was added to each well to give a final concentration range of $2.5-0.019 \mathrm{mg} / \mathrm{mL}$. The plates were incubated overnight for $M$. smegmatis and 3 days for $M$. aurum and M. fortuitum in incubator at $37^{\circ} \mathrm{C}$. To indicate bacterial growth, $40 \mu \mathrm{L}$ of $0.2 \mathrm{mg} / \mathrm{mL}$ INT ( $p$-iodo-nitro-tetrazolium) was added to each well after incubation and the plates incubated further at $37^{\circ} \mathrm{C}$ for $1 \mathrm{hr}$. The MIC was defined as the lowest concentration that inhibited the colour change of INT (yellow to purples). The experiment was performed in triplicate.

The MBC was determined by adding $50 \mu 1$ of the suspensions from the wells, which did not show any growth after incubation during MIC assays, to $150 \mu \mathrm{L}$ of fresh broth. These suspensions were re-incubated at $37^{\circ} \mathrm{C}$ for $24 \mathrm{hr}$. The MBC was determined as the lowest concentration of extract which inhibited $100 \%$ growth of microorganisms.

\section{Antioxidant assay \\ $\mathrm{DPPH}^{\circ}$-radical-scavenging assay}

The antioxidant activities of the samples were measured in term of radical scavenging ability using the stable radical (DPPH) of BrandWilliams et al. (1995) with some modifications. Methanol solution $(40 \mu \mathrm{L})$ of the samples at various concentrations $(15.62-2000 \mu \mathrm{g} / \mathrm{mL})$, and positive control (trolox and ascorbic acid) at concentration $(0.31$ to $40 \mu \mathrm{g} / \mathrm{mL})$ were added to $160 \mu \mathrm{L}$ of DPPH in methanol $(0.1 \mathrm{mM})$ in a 96 wellmicrotitre plate. Then, the change in absorbance $(517 \mathrm{~nm})$ was measured after $30 \mathrm{~min}$ with a microtitre plate reader (BioTek®). DPPH free radical scavenging ability (\%) was calculated by using the formula:

$$
\text { DPPH-scavenging effect }(\%)=\frac{A_{\text {control }}-A_{\text {sample }}}{A_{\text {control }}} \times 100
$$

The concentration providing $50 \%$ inhibition $\left(\mathrm{IC}_{50}\right)$ was calculated from the graph plotting percentage of DPPH radical scavenged against the concentration.

\section{$\mathrm{ABTS}^{\circ+}$ radical scavenging assay}

The free radical-scavenging activity as a measure of hydrogen donating capacity was determined by using ABTS cation decolourization method of Re et al. (1999), with some modifications. ABTS solution (7 mM) was reacted with potassium persulfate $(2.45 \mathrm{mM})$ solution and kept in the dark at room temperature for $12 \mathrm{hr}$. Prior to running the assay, the ABTS radical solution was diluted with a 50\% methanolic solution to an absorbance between $0.7-0.8$ at $734 \mathrm{~nm}$. The extracts were serially diluted $(40 \mu \mathrm{L})(15.62-2000 \mu \mathrm{g} / \mathrm{mL})$ in 96 well-microtitre plate and $160 \mu \mathrm{L}$ of ABTS radical solution added to each well. The absorbance were taken exactly after 6 min of reaction $\left(\mathrm{A}_{\text {sample }}\right)$ and blank absorbance $\left(\mathrm{A}_{\text {blank }}\right)$ were prepared using the respective extracts without ABTS radical. ABTS free radical scavenging ability $(\%)$ was calculated by using the formula: DPPH-scavenging effect (\%)

$$
\text { ABTS-scavenging effect }(\%)=\left[1-\frac{A_{\text {sample }}-A_{\text {blank }}}{A_{\text {control }}}\right] \times 100
$$

The concentration providing $50 \%$ inhibition $\left(\mathrm{IC}_{50}\right)$ was calculated from the graph plotting percentage of $\mathrm{ABTS}^{\circ}$ radical scavenged against the concentration.

\section{Ferric Reducing Antioxidant Power (FRAP) assay}

The FRAP of essential oil samples was determined by direct reduction of potassium ferricyanide $\left(\mathrm{K}_{3} \mathrm{Fe}(\mathrm{CN})_{6}\right)$ to potassium ferrocyanide $\left(\mathrm{K}_{4} \mathrm{Fe}(\mathrm{CN})_{6}\right)$ (electron transfer process from the antioxidant). The increase in absorbance from the formation of Pearl's Prussian blue complex following the addition of excess ferric ion was measured as described by Berker et al. (2007) with some modification. The reaction medium (210 $\mu \mathrm{L}$ ) containing $40 \mu \mathrm{L}$ of the test samples or positive controls (trolox and ascorbic acid; concentration range between: $15.62-2000 \mu \mathrm{g} / \mathrm{mL}$ ); $100 \mu \mathrm{L}$ of $1.0 \mathrm{M}$ hydrochloric acid; $20 \mu \mathrm{L}$ of $1 \%(\mathrm{w} / \mathrm{v})$ of SDS; $30 \mu \mathrm{L}$ of $1 \%(\mathrm{w} / \mathrm{v})$ of potassium ferricyanide, was incubated for $20 \mathrm{~min}$ at $50^{\circ} \mathrm{C}$. Then cooled to room temperature. Finally, $20 \mu \mathrm{L}$ of $0.1 \%(\mathrm{w} / \mathrm{v})$ of ferric chloride was added. The absorbance at $750 \mathrm{~nm}$ was read and blank absorbance was taken by preparing the reaction medium the same way except the addition of ferric chloride. The TEAC (Trolox Equivalent Antioxidant capacity) was calculated by dividing the slope of each sample (slope obtained from the line of best fit of the absorbance against concentration using the linear regression curve) by that of trolox.

\section{In vitro cell cytotoxicity activity (MTT assay)}

Cytotoxicity of essential oil was determined by MTT assay (Mosmann, 1983) using monkey kidney (Vero) cells and human hepatocellular carcinoma (C3A) cells. The C3A cells were obtained from the American Type Culture Collection (ATCC CRL-10741), and the Vero cells line were obtained from the culture collection of the Department of Veterinary Tropical Diseases (University of Pretoria). The preparation of cells culture was followed according to Makhafola et al. (2014). The cells were cultured in Minimal Essential Medium (MEM, Highveld Biological) supplemented with $0.1 \%$ gentamicin and 5\% foetal calf serum (FCS, Highveld Biological) for the Vero cells, and $10 \%$ FCS for the C3A cells. The cells of a sub-confluent culture were harvested using trypsin-EDTA (Sigma) and centrifuged at $200 \times g$ for 5 min and resuspended in growth medium to $5 \times 10^{4}$ cells $/ \mathrm{mL}$. 


\section{Sifi et al., Afr J Tradit Complement Altern Med. (2015) 12(3):150-155}

A total of $100 \mu \mathrm{l}$ of the cell suspension is pipetted into each well of columns 2 to 11 of a sterile 96 -well microtitre plate. A $200 \mu 1$ aliquot of growth medium was added to wells of columns 1 and 12 to minimize the "edge effect" and maintain humidity. The plates were incubated at $37^{\circ} \mathrm{C}$ in a $5 \% \mathrm{CO}_{2}$ incubator overnight and $100 \mu \mathrm{L}$ of different concentrations of essential oil samples prepared in MEM were added. Each dilution of the test sample was tested in quadruplicate. The microtitre plates were incubated at $37^{\circ} \mathrm{C}$ in a $5 \% \mathrm{CO}_{2}$ incubator for $48 \mathrm{~h}$. A negative control (untreated cells) and positive control (cells treated with different concentrations of doxorubicin chloride, Sigma) as well as an acetone solvent control, were included. After incubation, cells were washed with $200 \mu \mathrm{L}$ phosphate buffered saline (PBS) and fresh MEM (200 $\mu \mathrm{L}$ ) was added to each well together with $30 \mu \mathrm{L}$ of MTT (Sigma, stock solution of $5 \mathrm{mg} / \mathrm{mL}$ in PBS), the plates were incubated for a further $4 \mathrm{hr}$ at $37^{\circ} \mathrm{C}$. Then, the medium was carefully removed from the wells without disturbing the MTT concentrate and washed twice with PBS and 50 $\mu$ L of DMSO was added to each well to dissolve the crystallized MTT formazan. The amount of reduced MTT was measured at 570nm using microtitre plate reader (VersaMax, Molecular Devices). The wells in columns 1 and 12, containing medium and MTT but no cells were used to blank the microplate reader. The percentage of cell viability was calculated using the formula below:

$$
\% \text { cell viability }=\left[\mathrm{OD}_{(\text {sample) }}-\mathrm{OD}_{(\text {blank }} / \mathrm{OD}_{(\text {control })}-\mathrm{OD}_{\text {(blank }}\right] \times 100
$$

Dose response curves were obtained by plotting the percentage growth of cells versus log concentration of the compound. The $\mathrm{LC}_{50}$ (50\% lethal concentration) values were calculated from a non-linear regression model of sigmoidal dose-response curve (variable) and computed using SigmaPlot 12.0® software. From the minimum inhibitory concentration (MIC) values and $\mathrm{LC}_{50}$ values the selectivity index values of each sample were calculated using the formula: $S I=L C_{50} / M I C$

The selectivity index values indicate relative safety of the plant extract, reflecting the ratio between toxicity and activity. A high selectivity index is an indication of a large safety margin between the concentration of the extract that is able to kill the bacteria and the concentration that is toxic to mammalian cells in this case.

\section{Results}

The results of the antimycobacterial activity of essential oil of Pistacia atlantica Desf collected from three regions in Algeria against three Mycobacterium species are presented in Table 1.

Table 1: MIC and MBC (mg/mL) values of essential oil of Pistacia atlantica Desf against three Mycobacterium species.

\begin{tabular}{|c|c|c|c|c|c|c|c|c|c|}
\hline \multirow[b]{2}{*}{ Samples } & \multicolumn{3}{|c|}{ M. smegmatis } & \multicolumn{3}{|c|}{ M. aurum } & \multicolumn{3}{|c|}{ M. fortuitum } \\
\hline & MIC & MBC & Ratio $^{a}$ & MIC & MBC & Ratio $^{a}$ & MIC & MBC & Ratio $^{a}$ \\
\hline Ain-oussera & 0.62 & 1.25 & 2 & 0.16 & 0.62 & 4 & 2.5 & $>2.5$ & 1 \\
\hline Kheneg & 0.31 & 1.25 & 4 & 0.31 & 1.25 & 4 & 1.25 & $>2.5$ & 2 \\
\hline Laghouat & 0.31 & 1.25 & 4 & 1.25 & 1.25 & 1 & 1.25 & $>2.5$ & 2 \\
\hline Rifampicin $(\mu \mathrm{g} / \mathrm{mL})$ & 50 & 200 & 4 & 3.12 & 12.5 & 4 & 12.5 & 25 & 2 \\
\hline
\end{tabular}

${ }^{a}$ Ratio $=M B C / M I C$

The three essential oils tested showed that MIC values ranged from 0.16 to $2.5 \mathrm{mg} / \mathrm{mL}$ and MBC values ranged from 0.62 to $>2.5 \mathrm{mg} / \mathrm{mL}$. $M$. fortuitum was the most resistant strains towards all the essential oil samples (MIC value varied between $1.25 \mathrm{and} 2.5 \mathrm{mg} / \mathrm{mL}$ ). The MBC values ranged from 0.62 to $>2.5 \mathrm{mg} / \mathrm{mL}$. The ratio (MBC/MIC) was calculated for all samples of essential oil to show the bactericidal or bacteriostatic effect against mycobacteria.

The antioxidant properties of essential oil of gall of $P$. atlantica were determined by DPPH, ABTS and FRAP. Results are presented in table 2. The $\mathrm{IC}_{50}$ values ranged between $417.61->2000 \mu \mathrm{g} / \mathrm{mL}$.

Table 2: Antioxidant activities of essential oil of gall of Pistacia atlantica Desf by DPPH, ABTS and FRAP assay.

\begin{tabular}{llll}
\hline \multirow{2}{*}{ Samples } & $\mathbf{I C}_{\mathbf{5 0}}(\boldsymbol{\mu g} / \mathbf{m L})$ & & TEAC $^{*}(\mathbf{m g} / \mathbf{g})$ \\
\cline { 2 - 4 } & $\mathbf{D P P H}$ & ABTS & FRAP \\
\hline Ain-oussera & 417.61 & 495.6 & 0.115 \\
Kheneg & $>2000$ & 1479.0 & 0.106 \\
Laghouat & $>2000$ & $>2000$ & 0.111 \\
Trolox & 7.68 & 2.99 & - \\
Ascorbic acid & 5.68 & 1.13 & 1.534 \\
\hline
\end{tabular}

*TEAC: Trolox Equivalent Antioxidant Capacity (mg of Trolox / $g$ of dried extract)

The results of the cytotoxicity summarized in table 3 and figure 1 showed that all the samples had lower toxicity. According to their collection area, the samples from Ain-oussera and Kheneg regions showed the lowest toxicity with LC50 values ranged from $93.64 \pm 1.07 \mu \mathrm{g} / \mathrm{mL}$ to 


\section{Sifi et al., Afr J Tradit Complement Altern Med. (2015) 12(3):150-155}

$225.40 \pm 1.19 \mu \mathrm{g} / \mathrm{mL}$ and from $80.58 \pm 1.03-100.20 \pm 1.29 \mu \mathrm{g} / \mathrm{mL}$ on Vero cell and C3A respectively. The selectivity index (SI) varied between 0.016 and 1.734 (table 4). The essential oil of P. atlantica collected from Ain-oussera had the highest SI (1.734) with M. aurum.

Table 3: $\mathrm{IC}_{50}$ of essential oil of gall of Pistacia atlantica Desf on Vero monkey and C3A cells.

Vero monkey kidney cells

Human hepatocytes (C3A)

\begin{tabular}{|c|c|c|c|c|c|c|}
\hline Samples & $\mathrm{LC}_{50}(\mu \mathrm{g} / \mathrm{mL})$ & SD & $R^{\wedge} 2$ & $\mathbf{L C}_{50}(\mu \mathrm{g} / \mathrm{mL})$ & SD & $\mathbf{R}^{\wedge} 2$ \\
\hline Ain-oussera & 93.64 & 1.07 & 0.993 & 225.40 & 1.19 & 0.995 \\
\hline Kheneg & 80.58 & 1.03 & 0.997 & 100.20 & 1.29 & 0.993 \\
\hline Laghouat & 26.47 & 1.10 & 0.998 & 74.29 & 1.08 & 0.992 \\
\hline Doxorubicin $(\mu \mathrm{M})$ & 3.32 & 1.31 & & 3.104 & 2.51 & \\
\hline
\end{tabular}

(a)

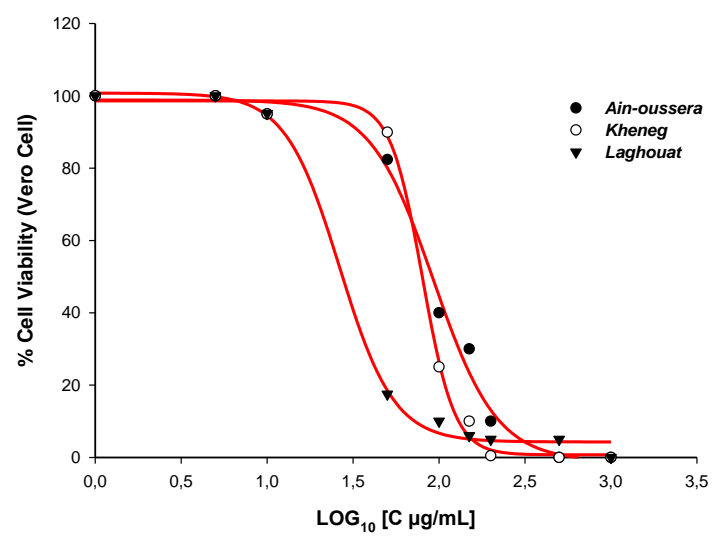

(b)

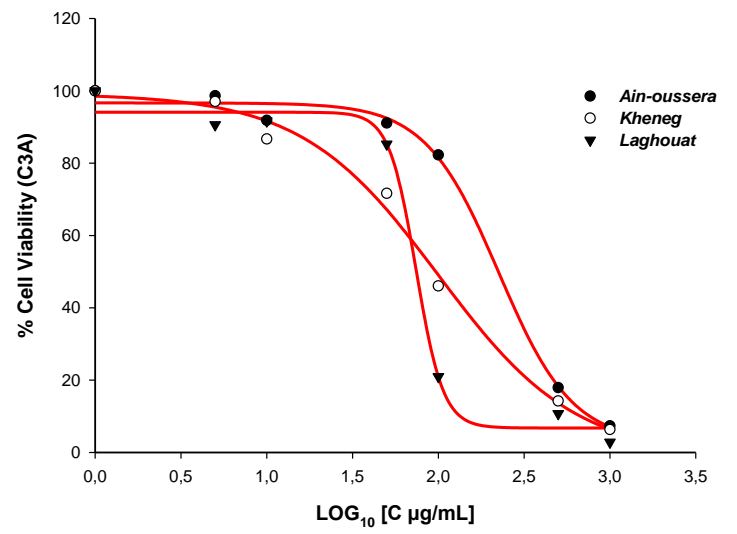

Figure 1:. Effect of essential oils of gall of P. atlantica Desf on the growth of Vero monkey (a) and C3A (b) cells.

Table 4: Selectivity index values of essential oils of gall of $P$. atlantica Desf on M. smegmatis, M. aurum and M. fortuitum and Vero monkey and C3A cells.

\begin{tabular}{llll}
\hline \multirow{2}{*}{ Cell lines } & \multicolumn{2}{c}{ Collection area } \\
\cline { 3 - 4 } & Ain-oussera & Kheneg & Laghouat \\
\hline Vero monkey kidney cells & 0.150 & 0.258 & 0.085 \\
$\quad \begin{array}{l}\text { M. smegmatis } \\
\text { M. aurum }\end{array}$ & 0.720 & 0.193 & 0.025 \\
$\quad$ M. fortutium & 0.022 & 0.064 & 0.016 \\
Human hepatocytes (C3A) & & & 0.238 \\
$\quad$ M. smegmatis & 0.361 & 0.321 & 0.071 \\
M. aurum & 1.734 & 0.240 & 0.045 \\
M. fortutium & 0.054 & 0.080 & \\
\hline
\end{tabular}

\section{Discussion}

The overall antimycobacterial activity of the three essential oils varied from moderate to weak. Similar results were revealed in an earlier study on the essential oils from plants collected in Colombia (Bueno et al., 2011). Nonetheless, the antimycobacterial activity of plantderived compounds against fast growing Mycobacterium species is well documented by several previous studies (Mossa et al., 2004; Seidel \& Taylor, 2004). Chung et al. (1995) showed that the activity against the rapidly growing $M$. aurum is highly predictive of the activity against $M$. tuberculosis, as the two species have similar drug sensitivity profiles. In this study, essential oil from Ain-oussera had the highest activity (MIC value of $0.16 \mathrm{mg} / \mathrm{mL}$ ) against $M$. aurum, giving some interest for further screening against pathogenic Mycobacterium species. According to Oussou et al. (2008), essential oil activity can be considered as bactericidal if the ration MBC/MIC < 4 and bacteriostatic if the ration MBC/MIC $>4$. Taking into account this cut-off, the activity of the three essential oils tested could be considered as bactericidal against $M$. smegmatis and $M$. aurum. The moderate antimycobacterial activity of the essential oil obtained in this study could be attributed to terpenoids derivatives. The 


\section{Sifi et al., Afr J Tradit Complement Altern Med. (2015) 12(3):150-155}

antimycobacterial potential of terpenoids derivatives have been previously demonstrated (Copp, 2003; Paduch et al., 2007). Gourine et al. (2011) reported monoterpenes such as $\alpha$-pinene and carene as major constituents of essential oils gall of $P$. atlantica.

The three various invitro assays used in this study are widely used to evaluate the free radical scavenging ability of plants. The use of at least two different assays in evaluating antioxidant activity of plant extracts has been recommended by Moon \& Shibamoto (2009). Compared to trolox and ascorbic acid used as standard antioxidant, the essentials oils tested possess weak antioxidant activity. These results are different of those previously obtained on the antioxidant activity of the essential oils from other parts of P. atlantica (Bachir Raho \& Benali, 2010; Gourine et al., 2010). However, the dissimilarity observed in this study could be explained by the differences observed in their chemical composition (Mecherara-Idjeri et al., 2008).

For a new anti-infectious drug candidate to be useful in clinical application, the preparation must be selectively toxic towards the targeted microorganism without major effects on host cells or interference with normal physiological pathways. Consequently, the three essential oils studied were tested for their toxicity against Vero monkey and C3A normal cell lines. In the categorization of crude extract safety, $\mathrm{LC}_{50}$ value of $20 \mu \mathrm{g} / \mathrm{mL}$ and below is considered as cytotoxic in according to US National Cancer Institute (NCI) plant screening program (Kuete et al., 2011). In this study, $\mathrm{LC}_{50}$ values greater than $20 \mu \mathrm{g} / \mathrm{mL}$ were recorded for the three essential oil tested, therefore their toxicity could considered as relatively low. Interestingly, the SI obtained with the essential oil of $P$. atlantica collected from Ain-oussera was promising. A selectivity index value greater than 1 for a sample increases the likelihood that its toxic and antibacterial components are different (Cho-Ngwa et al., 2010). Thus, elimination of these toxic components by manipulation of this essential oil may yield more suitable antimycobacterial product.

\section{Conclusion}

The results of this study showed that the essential oils from the gall of $P$. atlantica have low toxicity and moderate activity against fast growing M. smegmatis and $M$. aurum. These results substantiate their potential as used in the treatment of non tuberculous mycobacterial infections. This finding is predictive of their activity against $M$. tuberculosis, therefore, further study might be considered to investigate the activity against pathogenic Mycobacterium strains.

\section{Acknowledgements}

IS, MO and MY wish to thank MESRS in Algeria (Ministère de l'Enseignement Supérieur et la Recherche Scientifique) for his financial support to this study. The University of Pretoria provided a postdoctoral fellowship to JPD.

\section{References}

1. Bachir Raho, Ghalem, and Benali, Mohamed. (2010). Antimicrobial activity determination of the gum of Pistacia atlantica Desf. oil. African Journal of Microbiology Research, 4(23), 2457-2460.

2. Berker, K. I., Guclu, K., Tor, I., and Apak, R. (2007). Comparative evaluation of Fe(III) reducing power-based antioxidant capacity assays in the presence of phenanthroline, batho-phenanthroline, tripyridyltriazine (FRAP), and ferricyanide reagents. Talanta, 72(3), 1157-1165.

3. Billo, M., Cabalion, P., Waikedre, J., Fourneau, C., Bouttier, S., Hocquemiller, R., and Fournet, A. (2005). Screening of some New Caledonian and Vanuatu medicinal plants for antimycobacterial activity. J Ethnopharmacol, 96(1-2), 195-200.

4. Brand-Williams, W., Cuvelier, M. E., and Berset, C. (1995). Use of free radical method to evaluate antioxidant activity. Lebensm. Wiss. Technology, 28, 25-30.

5. Bueno, J., Escobar, P., Martinez, J.R., Leal, S.M., and Stashenko, EE. (2011). Composition of three essential oils, and their mammalian cell toxicity and antimycobacterial activity against drug resistant-tuberculosis and nontuberculous mycobacteria strains. Nat Prod Commun, 11(6), $1743-1748$.

6. Cho-Ngwa, Fidelis, Abongwa, Melanie, Ngemenya, Moses, and Nyongbela, Kennedy. (2010). Selective activity of extracts of Margaritaria discoidea and Homalium africanum on Onchocerca ochengi. BMC Complementary and Alternative Medicine, 10(1), 62.

7. Chung, G. A., Aktar, Z., Jackson, S., and Duncan, K. (1995). High-throughput screen for detecting antimycobacterial agents. Antimicrob Agents Chemother, 39(10), 2235-2238.

8. Copp, B. R. (2003). Antimycobacterial natural products. Nat Prod Rep, 20(6), 535-557.

9. Eloff, J. N. (1998). A sensitive and quick microplate method to determine the minimal inhibitory concentration of plant extracts for bacteria Planta Med, 64(8), 711-713.

10. Golan-Goldhirsh, A., Barazani, O., Wang, Z. S., Khadka, D. K., Saunders, J. A., Kostiukovsky, V., and Rowland, L. J. (2004). Genetic relationships among Mediterranean Pistacia species evaluated by RAPD and AFLP markers. Plant Syst. Evol, 246, 9-18.

11. Gourine, N., Yousfi, M., Bombarda, I., Nadjemi, B., Stocker, P., and Gaydou, E.M. (2010). Antioxidant activities and chemical composition of essential oil of Pistacia atlantica from Algeria. Industrial Crops Products, 31, 203-208.

12. Gourine, Nadhir, Sifi, Ibrahim, Gaydou, Emile M., and Yousfi, Mohamed (2011). Chemical composition of the essential oil of unripe galls of Pistacia atlantica Desf. from Algeria. Natural Products Journal, 1, 125-127.

13. Kuete, V., Krusche, B., Youns, M., Voukenga, 1., Fankam, A. G., Tankeo, S., . . . Efferth, T. (2011). Cytotoxicity of some Cameroonian spices and selected medicinal plant extracts. J Ethnopharmacol, 134, 803-812.

14. Makhafola, Tshepiso J., McGaw, Lyndy J., and Eloff, Jacobus N. (2014). In vitro cytotoxicity and genotoxicity of five Ochna species (Ochnaceae) with excellent antibacterial activity. South African Journal of Botany, 91(0), 9-13.

15. Martinez, J.-J. I. (2008). Impact of a gall-inducing aphid on Pistacia atlantica Desf. trees. Arthropod-Plant Interactions, 2, 147-151.

16. McGaw, L. J., Lall, N., Hlokwe, T. M., Michel, A. L., Meyer, J. J., and Eloff, J. N. (2008). Purified compounds and extracts from Euclea species with antimycobacterial activity against Mycobacterium bovis and fast-growing mycobacteria. Biol Pharm Bull, 31(7), 1429-1433.

17. Mecherara-Idjeri, S., Hassani, A., Castola, V., and Casanova, J. (2008). Composition of leaf, fruit and gall essential oils of Algerian Pistacia atlantica Desf. J. Essent. Oil Res., 20(3), 215-219.

18. Moon, J.K., and Shibamoto, T. (2009). Antioxidant assays for plant and food components. J Agric Food Chem, 5(57), 1655-1666. 


\section{Sifi et al., Afr J Tradit Complement Altern Med. (2015) 12(3):150-155}

19. Mosmann, T. (1983). Rapid colorimetric assay for cellular growth and survival: application to proliferation and cytotoxicity assays. J Immunol Methods, 65(1-2), 55-63.

20. Mossa, J. S., El-Feraly, F. S., and Muhammad, I. (2004). Antimycobacterial constituents from Juniperus procera, Ferula communis and Plumbago zeylanica and their in vitro synergistic activity with isonicotinic acid hydrazide. Phytother Res, 18(11), 934-937.

21. Oussou, K.R., Yolou, S., Boti, J.B., Guessennd, K.N., Kanko, C., Ahibo, C., and Casanova, J. (2008). Etude chimique et activité antidiarrhique des huiles essentielles de deux plantes aromatique de la pharmacopée Ivoirienne. European Journal of Scientific Research, 24, 94-103.

22. Ozenda, P. (2004). Flore et végétation du Sahara: CNRS Editions.

23. Paduch, Roman, Kandefer-Szerszeń, Martyna, Trytek, Mariusz, and Fiedurek, Jan. (2007). Terpenes: substances useful in human healthcare. Archivum Immunologiae et Therapiae Experimentalis, 55(5), 315-327.

24. Pinto, S. C., Leitao, G. G., de Oliveira, D. R., Bizzo, H. R., Ramos, D. F., Coelho, T. S., Leitao, S. G. (2009). Chemical composition and antimycobacterial activity of the essential oil from Anemia tomentosa var. anthriscifolia. Nat Prod Commun, 4(12), $1675-1678$.

25. Raju, Gautam., Arvind, Saklani., and Jachak, SM. (2007). Indian medicinal plants as a source of antimycobacterial agents. J Ethnopharmacol, 2(110), 200-234.

26. Re, R., Pellegrini, N., Proteggente, A., Pannala, A., Yang, M., and Rice-Evans, C. (1999). Antioxidant activity applying an improved ABTS radical cation decolorization assay. Free Radic Biol Med, 26(9-10), 1231-1237.

27. Rios, J. L., and Recio, M. C. (2005). Medicinal plants and antimicrobial activity. J Ethnopharmacol, 100 (1-2), 80-84.

28. Seidel, V., and Taylor, P. W. (2004). In vitro activity of extracts and constituents of Pelagonium against rapidly growing mycobacteria. Int $\mathrm{J}$ Antimicrob Agents, 23(6), 613-619.

29. Zanetti, S., Cannas, S., Molicotti, P., Bua, A., Cubeddu, M., Porcedda, S., Sechi, L. A. (2010). Evaluation of the Antimicrobial Properties of the Essential Oil of Myrtus communis L. against Clinical Strains of Mycobacterium spp. Interdiscip Perspect Infect Dis, 2010. 